\title{
Balancing Under and Over Communication in Sustainability ${ }^{*}$
}

\author{
Eric Pezet ${ }^{* *}$, Cecilia Casalegno ${ }^{* * *}$
}

\begin{abstract}
As all-sized profit organizations mostly compete both globally and locally, they have to think about a combination of strategies that have increasing social and environmental impacts, naturally dictated by a wider range of actions. Problems frequently arise from firms' inability to successfully balance these two business functions: Communication and CSR. Both functions should take into account all the firm stakeholders simultaneously and they frequently meet, as they both ultimately aim at understanding the links between society, communities, the economy and ecosystems. Considering this, a model which analyses the different types of communication suited to each dimension of the integrated CSR is proposed. The elements of this model, can help organizations to avoid traps represented by the so called under and over communication.
\end{abstract}

Keywords: Corporate Social Responsibility; Corporate Communication; Integrated Communication; Corporate Reputation; Sustainability; Global Markets

\section{Communication and Corporate Social Responsibility}

One of the main challenges firms have face today is linked to changing trends and the need to adapt and re-adapt their existing business model. As profit organizations of all sizes mostly compete both globally and locally, they have to think about a combination of strategies that have increasing social and environmental impacts, naturally dictated by a wider range of actions. Two main challenges also have to be highlighted: first, Corporate Social Responsibility (CSR) is more than a strategic corporate function, it is the basis for competitive advantage, since it has to respond to and to be in line with stakeholders' current expectations (Salvioni \& Bosetti, 2014, Perrini \& Vurro, 2013; Arrigo, 2009; Ricotti, 2003). Second, firms today are strengthening their efforts to build and maintain strong relationships with their different audiences, since they literally have to communicate to stakeholders and do so in a strategic way, to avoid misjudgements.

Problems frequently arise from firms' inability to successfully balance these two business functions: communication and Corporate Social Responsibility (CSR), seen as fundamental to reputation, which is a key aspect of business performances (Perrini

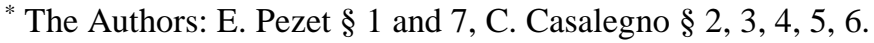

** Full Professor of Management, University of Paris Nanterre (eric.pezet@u-paris10.fr)

*** Researcher and Lecturer of Management, University of Turin (cecilia.casalegno@ unito.it)
} 
\& Vurro, 2013; Perrini \& Vurro, 2010). In fact, organizations often tend to overemphasize their CSR efforts or seem to forget to communicate their involvement in local social and environmental problems. In both cases, the corporate image can be damaged, since firms today are expected to give evidence of their social and environmental commitment, and transparency is fundamental requirement (Salvioni \& Bosetti, 2014). Corporate communication is seen as a transversal and integrated strategic function and one of the major drivers of so-called global capitalism (Brondoni, 2014). It should be recalled that its main task is to sustain and protect a company's reputation by nurturing and maintaining long term and strong relationships with stakeholders, which are increasingly crucial (Brondoni, 2011).

On the other hand, CSR is an integrated, strategic business function (Casalegno \& Civera, 2016) and has numerous environmental, social, ethical and economic purposes which originate in communication and multi stakeholder-value relationships.

CSR is strategic, as all its activities offer the most powerful way to take advantage of differentiation (Perrini \& Vurro, 2013; Perrini, 2005). Clearly, with both functions, one should take into account all the firm stakeholders simultaneously. These functions frequently intersect, as they both ultimately aim at understanding the links among society, communities, the economy and ecosystems (Casalegno \& Civera, 2016). This is the why integrated communication is so important (Romoli et al., 2014; Van Riel \& Fombrun, 2007; Brondoni, 2006; Gnecchi, 2006; Kitchen \& Schultz, 2003; Albanese, 2001), as is integrated CSR (Freeman et al., 2010; De Colle \& Gonella, 2003).

Just as the implementation of CSR may provide a solution to opposing interests, integrated communication of actions and initiatives may serve as a strategy for establishing the aforementioned long-term relationships. To be more precise, integrated communication of CSR actions and initiatives may increase and improve certain key concepts which multiple authors consider the basis of corporate communication: corporate personality, identity, image and reputation (Siano et al., 2015).

For instance, Coviello and Brodie (1998) view the relational approach with the target market as the base upon which one builds stronger results and a stronger brand image. This influences the customer experience of a certain brand, affecting its reputation (Veloutsou \& Moutinho, 2009).

Consequently, target attitudes, together with customer intent to purchase, may be influenced by responsible and sustainable initiatives. In other words, when the CSR communication is well developed within an articulate, organic and constantly evolving plan, it has a positive impact on the target market and on its perception of the company's reputation (Matute-Vallejo et al., 2011; Pomering \& Dolnicar, 2009; Sen $\&$ Bhattacharya, 2001). A good reputation may more quickly develop the brand (Werther \& Chandler, 2005; Wheeler, 2009; Aaker, 2010; Candelo et al., 2014; Hur et al., 2014), as every firm must demonstrate its global and local citizenship (Lambin $\&$ Brondoni, 2000).

Considering this, managers can follow a framework to analyse and plan the different types of communication suited to each dimension of the integrated CSR, i.e., 'standards and norms' (De Colle et al., 2014), which refer to the firm's reporting activity in compliance with the law or general convention, as well as 'strategic philanthropy' (Porter \& Kramer, 2002), which identifies activities designed to meet 
communities' demands for increased support of projects and initiatives linked to development of local social interests. Finally, 'integrated outputs', referring to products, services, processes and policies, are intrinsically linked to the concept of CSR (Casalegno \& Civera, 2016). The elements of this framework, which are based on best practices as derived from the literature as well as case analyses, may help organizations to the avoid traps of over communication or, at the other end of the spectrum, inadequate communication in CSR. Managers who recognize the importance of both integrating CSR and communication and balancing the communication of CSR output generally see their firms outperform the market.

\section{The Importance of an Integrated Communication}

As stakeholder theory maintains (Freeman et al., 2010), all stakeholders contribute to the value creation process through common action, despite their different interests. In the current economy, the purpose of each player is to find a balance among economic growth, environmental safeguards and social justice (Lambin, 2009), as the basis of value creation is now collaboration rather than competition. This is especially true from a communication standpoint, as all audiences are equally important to a firm (Casalegno, 2015).

The importance of well-balanced communication is highlighted by Lambin (2009), for whom firms may reach a long-term competitive advantage by switching from an industrial mind-set to a relational one. Communication represents one of the four pillars of 'global capitalism' (Brondoni, 2014), as it underlines the importance of bottom-up collaborative relationships, continuous and good tools to create confidence among stakeholders and the firm itself.

A long-term planning strategy incorporating different types of communication is the main objective of those responsible for a firm's communication. Firms must standardise communication fundamentals by integrating corporate identity values into every message, into its relationship with stakeholders and in the practical implementation of its communication tools.

This is despite the fact that communication is aimed at a wide array of audiences: consumers, shareholders and investors, employees, suppliers and local communities.

All communication types designed for different levels of interests should be integrated through concerted actions aiming at 'harmonizing communication flows' (Siano et al., 2015), which are increasingly complex (Brondoni, 2011). Integrated communication is a fundamental requirement of corporate communication (Brondoni, 1993; Collesei, 2002; Collesei \& Ravà, 2008). This is how a firm's integrated communication is defined. Corporate communication represents the core of building and nurturing relationships between stakeholders of a certain market and relevant communities.

This enables these relationships to become long-lasting and equalizing, as some studies argue (e.g., Bellini \& Brondoni, 2016; Siano 2015; Brondoni \& Gnecchi, 2011; Muzi \& Falconi, 2004; Grunig, 2001). 
Figure 1: The Firm Communication Integration

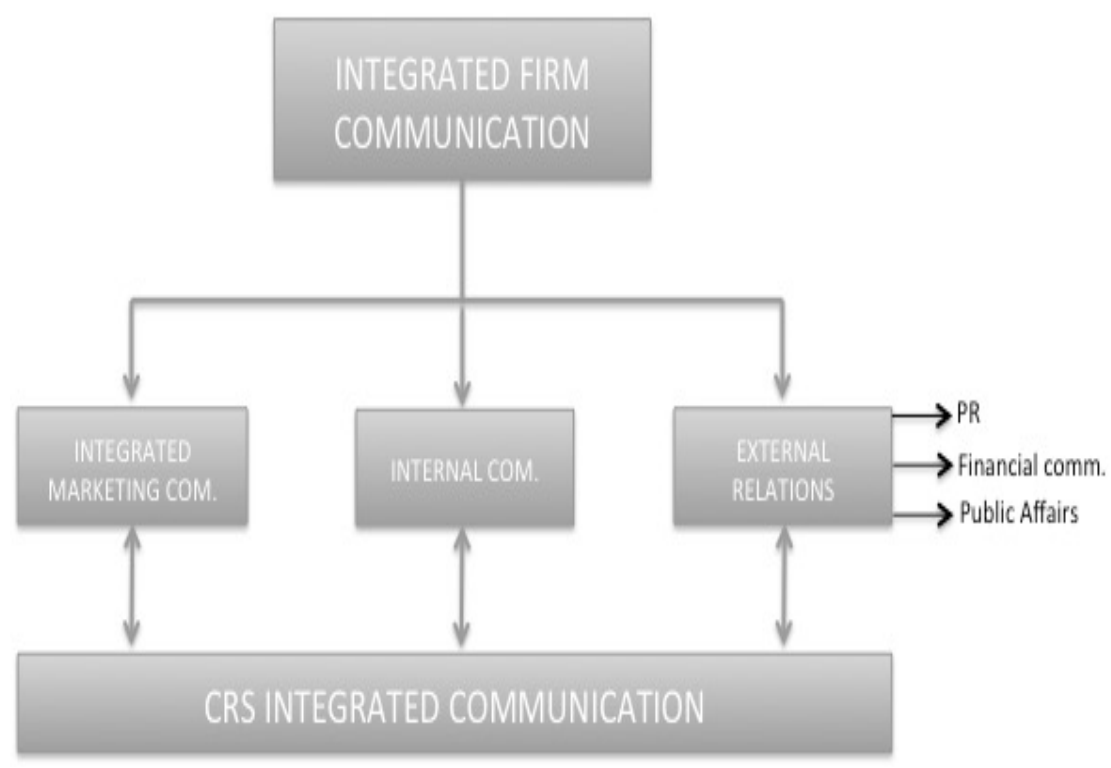

By simultaneously making the most of the media used by certain audiences, it its possible to capture all their entire attention and engage them completely in the message.

This media integration represents, on one hand, the opportunity to surround a certain audience, but, on the other hand, it can be the reason for confusing integrated marketing communication with corporate communication, or the other kinds of firm communication.

As Figure 1 shows, the CSR communication is transversal to the other systems of communication (integrated marketing communication, internal communication and external relations), as it may positively impact the corporate image and corporate reputation (Siano et al., 2015), which are considered the firm's major value creation sources (Perrini \& Vurro, 2013).

Finally, for firms it is mandatory to consider the communication as an integrated and strategic function, since we are not just talking about a mean through which strategically (Siano, 2012) reaching the audiences, but rather a set of coordinated and consistent messages which take the firm itself to the external environment meeting, at the same time, all the other firm's functions.

It is better to talk about an integrated firm's communication, since it goes beyond the various goals, which every single firm's message aims at: every firm can obtain a satisfying long-lasting profit if it can build, protect and maintain a high reputation and the corporate communication does act both as springboard and shield of the firm reputation: this is the real aim of this integrated firm function.

Moreover, gaining a certain level of reputation implies a better chance of creating and maintaining stakeholders' long-term confidence. Finally, the firm's reputation itself takes managers to social, environmental and local economy concerns and whether and how to communicate sustainable efforts and results is not easy. It always takes to the managerial embarrassment concerning how to handle the corporate brand, together with CSR promises and results. In fact, managers are continuously striving for confronting balancing financial results with effective CSR purposes and actions (Lambin, 2009). 


\section{CSR Dimensions and the Importance of their Communication to Enhance the Reputation}

The integrated CSR implementation allows firms gain access to new markets, cutting resources spending and social costs. It also improves relationships with stakeholders and this increases a positive communication, which can also affect financial markets (Salvioni \& Bosetti, 2014). Firms' reputation comes from a strong familiarity (Fessin \& Buelens, 2011), which stakeholders feel towards a certain organization and the brand itself can impact it, together with its values. This leads to stakeholder trust (Salvioni \& Bosetti, 2014; Perrini \& Vurro, 2010) and, in the long period, a certain level of confidence: it is about a deep relationship with supply chain members, a better customer engagement, a higher local community awareness and commitment, employees sense of belonging and increase their level of satisfaction (McWilliams, Siegel, 2001; Dawkins, Lewis, 2003). Recent research brings the light sustainability aims and they complement the theory that sustainability is key for a better communication with all stakeholders (Vallaster at al., 2012; Perrini, Vurro, 2013; Candelo et al., 2014). CSR communication is fundamental for creating awareness of corporate initiatives. It also determines social, ethical and environmental issues, and strengthens commitment of those groups interested in a certain company. Responding to these needs entails creating a code, which facilitates firm's relationships resulting in one clear message that can be accepted by all levels of stakeholders. Freeman et al. (2010) suggest that when a firm has a strong purpose, which can be turned into sustainable performances, it can more easily achieve its aims. As businesses increasingly refer to social, environmental and ethical aims and the relevant strategies connected to it, they become part of their responsibility. Implementing sustainability strategies can provide a common answer to different interests, equally, integrating communication of actions and initiatives can be considered a strategy to initiate this dialogue (Salvioni, Bosetti, 2014). To be more precise, integrated communication of CSR actions and initiatives can help increase and spread certain key concepts that the literature considers as corporate communication fundamentals: corporate personality, identity, corporate image (Siano et al., 2015), reputation (Siano et al., 2015; Salvioni, Bosetti, 2014; Gnecchi, 2006) and credibility (Ricotti, 2003).

It is therefore possible to build a model to analyse different types of communication for each CSR dimension:

1. "standard and norms" (De Colle et al., 2014), which refers to a firm reporting activity, in compliance with the law or general convention;

2. "strategic philanthropy" (Porter, Kramer, 2011), which represents all those activities carried on to satisfy communities' demands and supporting local development projects and social initiatives;

3. "integrated outputs", referring to products, services, processes and policies, linked intrinsically to the CSR concept (Casalegno \& Civera, 2016). 
Figure 2: The Sustainability Communication Framework

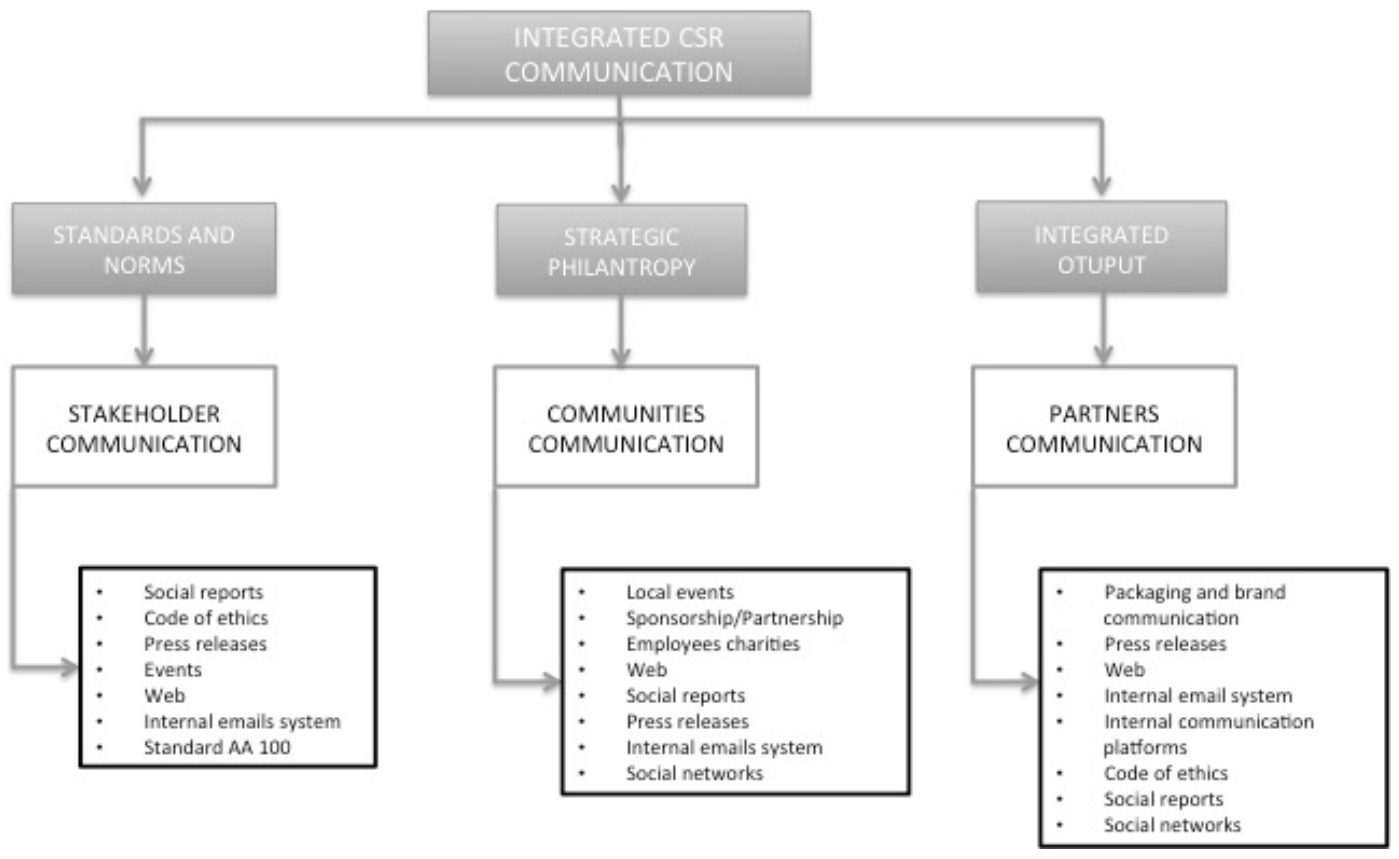

Firms must disseminate and obtain a sense of legitimisation of their actions during general communication with stakeholders (Salvioni, Bosetti, 2014). By using a common code, this communication aims to inform a firm's stakeholders of its initiatives (and results) of responsibility and sustainability. This type of communication is based on sustainable reports (Financial Statements, Sustainability Report), on codes of conduct, ethical codes, press communications (the main PR tool), local events, official web pages, and the internal mail system (since, as already mentioned, employees are strategic). Corporate communication is the most suitable one in this case, since messages concerning the firm brand represent the mean through which all stakeholders are informed of managerial policies over environment, diversity management, inclusion of protected categories within the business structure, quality standards, ethics and human rights. The second type of communication refers to build and feed relationships with the communities that are, in various ways, influenced by the firm itself. In this case, the firm aims at maintaining relationships with local communities to be perceived as a good citizen of the territories on which it is present. The best way to communicate the firm citizenship (Lambin, Brondoni, 2000) is to plan local events, sponsorships and partnership with local players and local stakeholders. Even spreading results over employees voluntary can help, together with, even in this case, web sites contents, a focused social media strategy, social reports, press releases and the internal emailing system. Eventually, partner communication (employees, suppliers, retailers, customers/consumers/users), is about all the firm undertaken actions concerning product (good or service) and implemented process and policies. Among those it is possible to talk about a reduced-impact process in the production, the use of compostable or biodegradable materials (since they are outputs of different processes) or raw materials, sustainable policies concerning the supply chain and/or the employee management. The most useful tools to spread this kind of communication are, again, institutional web sites (maybe with a thematic section), 
along with social network pages, reporting on sustainability, code of ethics, financial statements, and internal communication platforms. Another example of partner communication is the product itself in terms of packaging; it is not just about the written it is possible to find on it, but if the material is recycled, compostable or totally biodegradable, this represents a good way to communicate the firm environmental commitment. Furthermore, policies towards employees, welfare internal rules represent interesting contents of this last communication type: this is what is possible to "internal philanthropy" (Casalegno, Civera, 2016). CSR communication should be homogenous, frequent and transparent (Salvioni, Bossetti, 2014) and this should be valid for every dimension and every aspect of the corporate social responsibility. This is totally consistent with the concept of integrated communication which leads to the managerial effort of planning a communication strategy which can be consistent with the core business and the strategic goals a firm wants to reach in the long while. CSR strategy and the communication one are to be integrated each other, since "CSR should be matched with a transparent communication, which demonstrates firms' economical, environmental and social behaviours sustainability" (Perrini, 2005).

\section{Corporate and CSR Communication: Solving the Problem}

CSR dimensions like standards and norms (De Colle et al., 2014), strategic philanthropy (Porter, Kramer, 2002) and integrated outputs (Casalegno. Civera, 2016) are increasingly used not only as intangible assets which confirm values and promises of ethics and sustainability. They are also considered as tangible assets designed to guarantee a long lasting competitive advantage. After having implemented integrated CSR activities, the firm focuses its communication efforts on the same values, promises and results to both its internal and external audiences. This is to gain recognition of being a responsible business in terms of reputation and confidence (Perrini, Vurro, 2010), as said earlier. In the light of literature review, from a reputational point of view, CSR appears as communication driver for building corporate image that internal and external stakeholders will commonly define "ethical" (Salvioni, Bosetti, 2014; Perrini, Vurro, 2013). So, CSR becomes a foundation of communication by spreading, for example, social media messages concerning compostable product packaging and confirming of new partnerships with an NGO. This should influence consumer choices, audience opinions and increase both the public confidence towards a firm and consequently its reputation and value. However, in this light we see confirming CSR as a communication driver as limiting, because it is only one aspect of a greater system. CSR is the base of this system and becomes a corporate function that should be further integrated with the communication function and serving each other. Only strategically integrated communication with coherent and transparent content designed to communicate performance and tangible results can publish CSR standards and norms, strategic philanthropy and integrated output consequently increasing their legitimacy. On the other hand, the more CSR is strategically implemented with the aim of simultaneously creating economic and social value, the more it will be an efficient and transparent driver of its own communication. The problem can be solved without trying to prioritize one or the other function and recognizing that both are integrated 
into one system, affecting the whole organization including its internal and external relationships. From this perspective, integrated CSR (the content) and integrated communication (the form and the code through which the content is spread), being part of the same system, increase effectiveness of their mutual goals. Thus, the implementation of a firm CSR which is internally integrated means focus the whole organization to reach concrete goals, with tangible impacts on both internal and social and external environmental management.

\section{Figure 3: CSR as Content, Communication as Form}

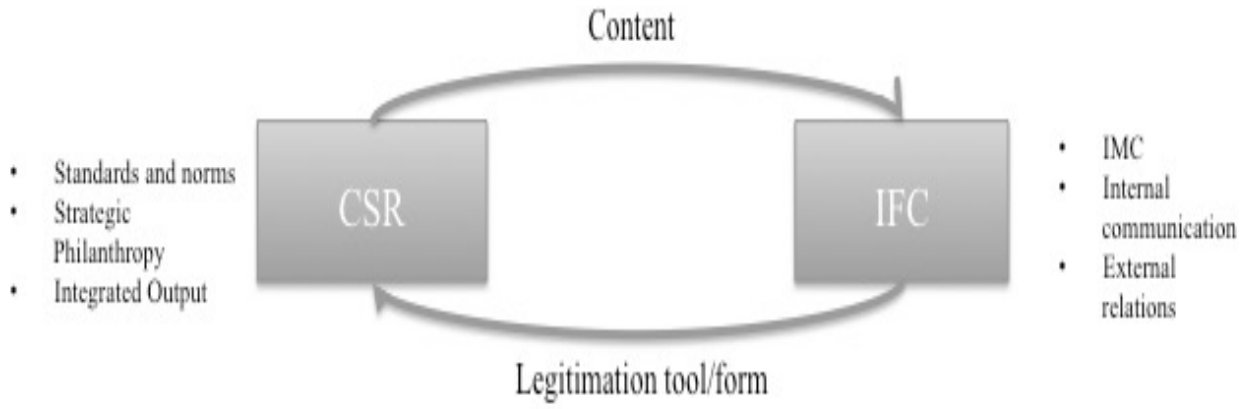

When CSR promises in terms of values and ethical principles are aligned with firms' performances and their communication, it means that the CSR has created social and economical value and that the communication has given its contribution to positive financial repercussions (Werther \& Chandler, 2005).

Figure 4: The Integrated CSR Communication Virtuous Cycle

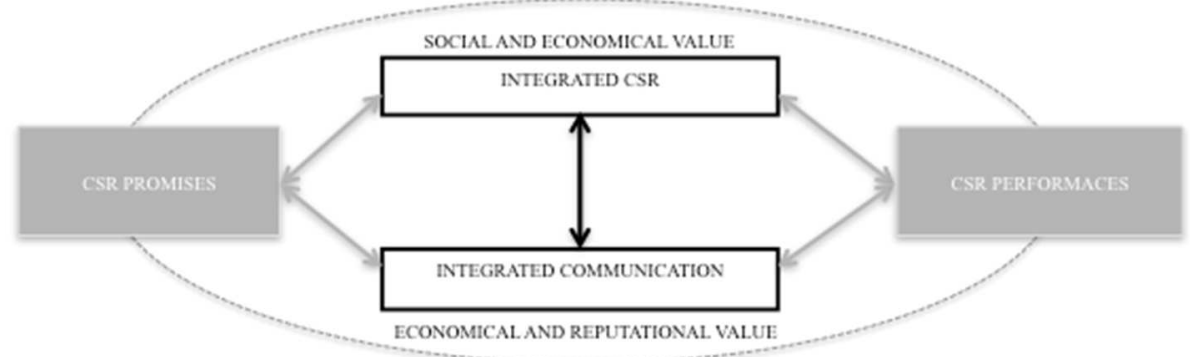

Even the firm reputation can benefit from that, by augmenting, for example, brand value and awareness, together with the loyalty and the confidence of the different audiences. Like in a virtuous cycle, the creation of economical and social value, together with a firm reputation, will go on until CSR promises and performances are aligned and CSR and communication are integrated to each other. Furthermore, the audience itself tends to legitimize information rather than communication. That is why, in the virtuous circle shown in Figure 4, the CSR performance integrated communication, which reflects the promises concretely, becomes an element of information that consists in making audiences aware of the actual achievements and alignment between these and promises and helps to reduce the reputation risk (Siano, 2012). 


\section{Unbalanced Communication and Stakeholders' Misjudgements: Finding a Solution}

The balance between CSR promises and true achievements is a difficult objective to reach, as well as to communicate. Visser (2012) states that effective CSR can be pursued when a CSR leader exists. It means that if in a firm the same person, who is in charge to command, is also accountable for the CSR strategy, this will lead to better results. When this doesn't happen, and different managers are in charge for the communication and the CSR functions, they at least need to co-operate and constantly interact, because communication does not give emphasis to promises, but space for actions and related results. This is the CSR communication that can be defined as "integrated" and it is characterized by transparency, completeness, and promptness (Brondoni, Gnecchi, 2011). When it is well balanced, it is also circular and multilateral (Casalgno, Civera, 2016; Romoli Venturi et al., 2014). Unbalance situations between communication and CSR result in two scenarios, depending on whether one prevails rather than the other (see Figure 5). The first situation involves the preponderance of communication with different purposes than informing about CSR actions and results and can be defined as CSR over communication (Casalegno, Civera, 2016). This is the use of CSR as a "simple" driver for traditional brand communication in order to improve the brand image and its awareness. Literature suggests that often the will to get these benefits leads to the propagation of messages with inconsistent ethical content (Jahdi, Acikdilli, 2009) and this leads the audience to creating false brand perceptions. In fact, nowadays the public may have access to a lot of information on this or that firm and can gain evidence of real business conduct more easily than in the past (Hur et al., 2014; van de Ven, 2008). CSR over communication results can be summarized as: promises and CSR intentions communications; not achieved yet CSR performance communication; communication of those CSR activities which are not connected to a strategy or to firm core business. Over-communication may also lead to a trap, green washing, that takes to a decline in reputation, which is defined (Delmas, Cuerel Burbano, 2011) as two firm's behaviours intersection: the inability to achieve certain environmental performances (in terms of sustainability and impacts) and over-communication on never reached environmental performance.

Figure 5: CSR Communication Model

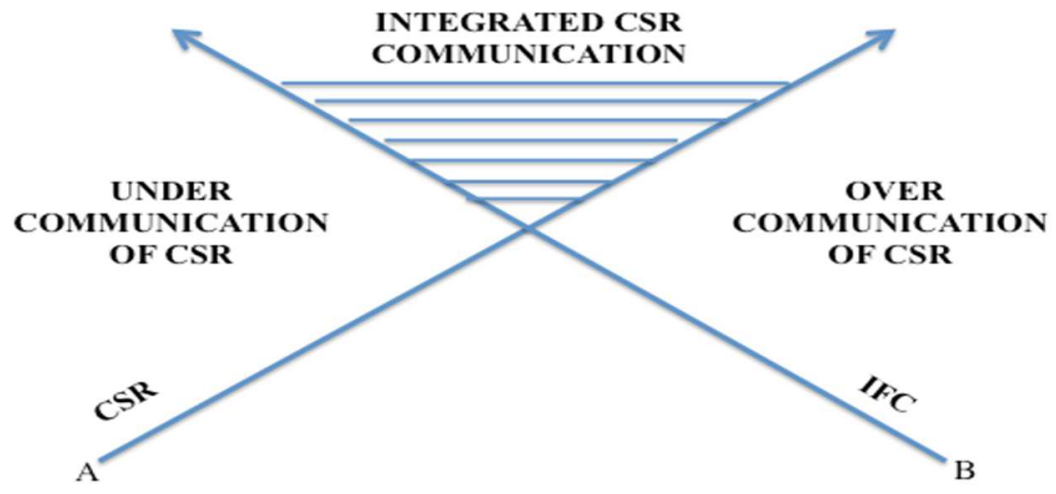

However, even the organization that achieves CSR-related results consistent with core business can fall into the mistake of not communicating actions to promote 
social, environmental, and economic sustainability, and this silence can be defined as CSR under communication (Casalegno, Civera, 2016). Under communication situations could be relied to the denial of some integrated CSR actions' business intentions and the scarce information about CSR's operational performance. Drivers, which lead to this behaviour, are related to the market in which firms play (which have, for example, intrinsic business-related prejudices) and the fear of falling into the CSR over communication error. This silence on sustainability-achieved results can be perceived by the public as a will to hide unethical performances or unfulfilled CSR promises. So the audience reaction will have equally negative impacts on trust and the creation of a long-term relationship between business and stakeholder.

\section{International Best Practices to Build "Universal Rules"}

Literature shows that how a firm communicates its CSR activities has a direct impact on its reputation (Salvioni, Bosetti, 2014; Hanss, Böhm, 2011; Fassin, Buelens, 2011, Perrini, Vurro, 2013; Perrini, Vurro, 2010; Ricotti, 2003). It is a matter of what a firm communicates, but also how it does it. In fact, as it is possible to read in the 2017 Global Rep Trak Report, local communities feel closer to a certain firm when it is perceived as familiar and this familiarity increases its chance to be seen as more sustainable. The relationship between reputation and CSR communication is to connect with the concept of familiarity: the more people are aware about a certain organization, the more they will judge its activities with real knowledge of the facts. In particular, when an organization conducts sustainable actions, the more familiar the stakeholders are, the more they feel involved in those actions, leading to an increase of the firm's reputation.

Through the case analysis methodology we can understand what a firm can or cannot do when its promises or facts concerning the three CSR dimensions need to be communicated. In order to extrapolate main behaviours to analyse and emerging issues to underline concerning CSR communication, we examine the Reputation Institute global rankings 2017 Global RepTrak® 100 and 2017 Global CSR RepTrak®. When selecting cases to analyse, we considered both rankings' top ten firms as five cases out of ten.

These cases are: Lego (first place for CSR and second place for reputation); Google (third place for CSR and fifth place for reputation); Walt Disney (fourth place for CSR and third place for reputation); Intel (sixth place for CSR and eighth place for reputation); Bosch (seventh place for CSR and sixth place for reputation).

Each case presents interesting examples of a CSR that is totally integrated in the business and all these firms use CSR integrated communication, without falling into under or over communication traps. It is to underline that we didn't evaluate as a plus the classical stakeholder communication, already defined as the communication through which a firm communicates the considered sustainable standards and norms. In fact, this is a common communication and every firm present in the two analysed ranking does it.

In order to collect data, official web sites, sustainability report and Reputation Institute's follow-ups were analysed. First of all, from the organizational point of view, in the considered cases the head of communication is also in charge for leading the firm CSR development. 
Table 1: International Benchmarking of CSR and Firms Reputation

\begin{tabular}{|c|c|c|c|c|}
\hline & $\begin{array}{l}\text { INTEGRATED } \\
\text { OUTPUT }\end{array}$ & $\begin{array}{l}\text { STRATEGIC } \\
\text { PHILANTROPY }\end{array}$ & $\begin{array}{l}\text { CSR AND } \\
\text { COMM. } \\
\text { INTEGRATION }\end{array}$ & STORYTELLING \\
\hline LEGO & $\begin{array}{l}\text { Lego Sustainable } \\
\text { Materials Centre; }\end{array}$ & $\begin{array}{l}\text { Local communities } \\
\text { engagement; Bringing } \\
\text { students' voice to life } \\
\text { through technology: } \\
\text { Lego Foundation }\end{array}$ & $\begin{array}{l}\text { Matt Withby: } \\
\text { Communication } \\
\text { Manager for } \\
\text { Corporate } \\
\text { Responsibility } \\
\end{array}$ & $\checkmark$ \\
\hline GOOGLE & $\begin{array}{l}\text { Google Food } \\
\text { Program; "Saving } \\
\text { Energy" Programs; }\end{array}$ & $\begin{array}{l}\text { Responding to the } \\
\text { refugees crisis; Data } \\
\text { Driver-human focused } \\
\text { philanthropy } \\
\text { (Google.org) }\end{array}$ & $\begin{array}{l}\text { CEO Sunder } \\
\text { Pichai (he } \\
\text { publicly talks } \\
\text { about social } \\
\text { inclusions) }\end{array}$ & $\checkmark$ \\
\hline $\begin{array}{l}\text { WALT } \\
\text { DISNEY }\end{array}$ & $\begin{array}{l}\text { Reducing emissions } \\
\text { programs; waste } \\
\text { management } \\
\text { programs }\end{array}$ & $\begin{array}{l}\text { Walt Disney } \\
\text { Foundation for } \\
\text { Children; employees } \\
\text { voluntary }\end{array}$ & $\begin{array}{l}\text { Zenia Mucha: } \\
\text { Chief } \\
\text { Communication } \\
\text { Officer (involved } \\
\text { in speaking about } \\
\text { sustainable } \\
\text { initiatives) }\end{array}$ & $\checkmark$ \\
\hline INTEL & $\begin{array}{l}\text { "2017 Largest } \\
\text { voluntary corporate } \\
\text { purchaser of green } \\
\text { power" }\end{array}$ & $\begin{array}{l}\text { Supporting bright } \\
\text { young minds; Intel } \\
\text { Foundation (evidence- } \\
\text { based, data-driven } \\
\text { solutions for } \\
\text { promoting social } \\
\text { inclusion }\end{array}$ & $\begin{array}{l}\text { Roz L. Hudnell: } \\
\text { Vice President of } \\
\text { Corporate Affairs } \\
\text { and President of } \\
\text { the Intel } \\
\text { Foundation }\end{array}$ & $\sqrt{ }$ \\
\hline $\begin{array}{l}\text { ROBERT } \\
\text { BOSH }\end{array}$ & $\begin{array}{l}\text { Co2 emissions } \\
\text { decrease } \\
\text { engagement; } \\
\text { sustainable mobility }\end{array}$ & $\begin{array}{l}\text { Primavera project: } \\
\text { helping children in } \\
\text { need; Robert Bosch } \\
\text { Foundation }\end{array}$ & $\begin{array}{l}\text { Bernhard } \\
\text { Schwager: head of } \\
\text { sustainability and } \\
\text { renown keynote } \\
\text { speaker over } \\
\text { sustainability }\end{array}$ & $\checkmark$ \\
\hline
\end{tabular}

This means that CSR and communication are integrated to make CSR efforts and their communication as transparent as possible: this is strategic and contributes to equate CSR to good will and good business. Considering the five cases, the Lego's communication manager is also accountable for CSR, the Google's CEO takes a firm stand for social inclusion concerns. Furthermore, the Walt Disney's chief of communication officer is the one who deals with the CSR communication, the Intel's vice president of Corporate Affairs is also in charge as President of the Intel Foundation (for philanthropy projects). Finally, the Bosch head of sustainability is a storyteller and a renowned keynote speaker over sustainable concerns. These facts generate the sense of familiarity that means that a firm can be perceived closer to its audience, and this has a great impact on the firm's reputation. In a nutshell, the capacity of communicating integrated outputs (already named as partner communication) both fluently and naturally, without trying to exploit sustainable actions just for advertising purposes, is one of the investigated elements: integrated outputs mostly speak for themselves, creating a closer collaboration between firm and stakeholders. Intel won the "2017 Largest voluntary corporate purchaser of green power"; Robert Bosch shows increasing commitment in sustainable mobility and emission decrease, as do Google, Lego (Sim, Putuhena, 2015) and Walt Disney. Also, when local communities are satisfied with firm's sustainable actions (communities communication), they perceive this firm as a good local citizen, leading them to be brand ambassadors. Every firm analysed promotes social 
programs helping people in accordance with its business and strategic goals. For example, the Intel Foundation plans evidence-based and data-driven solutions for promoting social inclusion and the Disney Foundation aims at improving children's quality of life. To improve stakeholders' knowledge of CSR actions, storytelling represents one main strategy. In fact, telling a real story engages the firm with society and when customers understand this strategy, they will accept companies' CSR actions more easily as they are more consistent with the core business. Eventually, should there be a scandal, people will more readily give these firms the benefit of the doubt. In fact, in the cases analysed, firms prefer to tell a story about their social and environmental concerns through dedicated web sites, online and printed social reports, official social network pages, and in-dash managerial interviews over the firm's commitment in local concerns. On the other side, the two rankings present worst practices, which represent good examples of what to avoid doing even if the above-mentioned conditions and elements are satisfied. For example, in 2017 Volkswagen is at the end of the two considered lists, since in 2015 its CSR Index has dropped by 13 points, because of the "Cheat Device scandal". Before that scandal, Volkswagen was knew as one of the most sustainable car brand (with its $14^{\text {th }}$ Global RepTrak ranking position and its $11^{\text {th }}$ Global CSR RepTrak position), due to its Foundation, which is non-profit organization with the aim of funding research projects in all disciplines. Furthermore, the famous carmaker is involved in several international projects, which concern people training, nature conservation, health care, culture and arts, regional support. However, all the efforts done by Volkswagen during the years, as responsible territorial citizen, couldn't save its reputation after the scandal and even though its managers publicly apologized and admitted the big mistake, people, in general, seem to have lost their confidence in it. On the light of the above, it will be interesting to evaluate Google stakeholder confidence (and its reputation evolution, tracked by the Reputation Institute) after the facts concerning the European taxes.

\section{Emerging Issues For Managers: A First Attempt}

CSR and communication managers, despite the fact that mostly the same person is in charge of both functions, can use some rules to enhance the CSR communication effectiveness. These rules can be accepted as emerging issues to consider, if a firm wants to outperform. In fact, as already stated, a better CSR communication leads to a better reputation and a better reputation leads to better economic results. In a nutshell, literature review and case analysis lead to the following managerial implications:

- Always integrate the two functions. Assuming that both communication and CSR have to pursue strategic goals by integrating themselves with all other functions, the maximum effectiveness of CSR messages is obtained when the two functions are aligned with a systemic view that allows them to achieve what we have defined as integrated CSR communication;

- Be careful in communicating promises. Intent communication doesn't lead to public trust and confidence. The more CSR messages talk about achieved results, highlighting the alignment between promises and the results themselves, the easier it will be to attract the audience's favour; 
- Do not deny your business. This is the territory of the transparent communication. Sustainable actions are undertaken because of their positive impact on a certain business: this is a message that people can easily understand and CSR must always be aligned with the brand purposes;

- Share your story with people. It deals with the act of telling the own real story, by focusing on stakeholders' relationships. Stakeholders want to be a part of the firm's story, especially when they could or can take advantage of the firm's actions, since effective CSR is about facts, not about rhetoric;

- Your actions talk instead of you. Participation in conferences and talk shows or round tables, texts written by a third part about a firm and its sustainable actions, the integrated output themselves: these speak louder and more effectively than any kind of firm's volunteer communication;

- If you fail, just admit it and apologize. It works especially when stakeholders are at your side, since you have always carried on the above-mentioned CSR communication actions;

- Be more open and genuine, because transparency always pays.

In a nutshell, awareness in not enough, but firms need to leverage familiarity, if they want to build strong and long lasting relationships with heir stakeholders.

Eventually, when corporate responsibility is embedded in the firm strategy and no kind of communication prevails over the others, but is embedded in a coherent and strategic plan, firms can take advantage of a natural stakeholder approach, which is interactive, intuitive, "flowing", not invasive or aggressive and is accepted by the whole audience for these reasons.

\section{Bibliography}

Aaker, D. (2010). Marketing challenges in the next decade. Journal of Brand Management March 2010, 17(5), 315-316.

https://doi.org/10.1057/bm.2010.2

Albanese, F. (2001), Merchandising and Licensing to Improve Brand Equity. The Coca-Cola Case, Symphonya. Emerging Issues in Management (symphonya.unimib.it), 1, 51-65.

http://dx.doi.org/10.4468/2001.1.06albanese

Arrigo, E. (2009). Market-Driven Management, Global Competition and Corporate Responsibility, Symphonya. Emerging Issues in Management (symphonya.unimib.it), 1, 54-70

http://dx.doi.org/10.4468/2009.1.06arrigo

Bellini, N. \& Brondoni, S.M. (2016). Ouverture de Global Tourism in Global Markets, Symphonya. Emerging Issues in Management (symphonya.unimib.it), 1, 1-6.

http://dx.doi.org/10.4468/2016.1.01ouveture

Brondoni, S.M. (2006). Corporate Communication and Global Markets. Symphonia, Emerging issues in Management, 2, 9-37.

http://dx.doi.org/10.4468/2006.2.02brondoni

Brondoni, S.M. (2014) Ouverture de 'Global Networks and Sustainable Development - 1', Symphonya. Emerging Issues in Management (symphonya.unimib.it), 1, 1 - 9.

http://dx.doi.org/10.4468/2014.1.01ouverture

Candelo Elena, Casalegno Cecilia, Civera Chiara (2014), Meanings and Implications of Corporate Social Responsibility and Branding in Grocer Retailers: A Comparative Study over Italy and the UK in Musso F, Druica E. (2014), Handbook of Research on Retailer-Consumer Relationship Development, IGI Global. 
http://dx.doi.org/10.4018/978-1-4666-6074-8.ch019

Collesei, Umberto (2002). "Brand tracking." paper presentato al Convegno Le tendenze del Marketing, Parigi, pp. 25-26.

Coviello Nicole, Brodie Roderick (1998), From transaction to relationship marketing: an investigation of managerial perceptions and practices. Journal of Strategic Marketing, vol. 6, n.3, pp. 171-186. http://dx.doi.org/10.1080/096525498346603

De Colle Simone, Gonella Claudia (2003), Corporate social responsibility: the need for an integrated management framework. International Journal of Business Performance Management, vol. 5, n. 23, pp. 199-212

https://doi.org/10.1504/IJBPM.2003.003254

De Colle, Simone; Henriques, Adrian; Sarasvathy, Saras (2014). The paradox of corporate social responsibility standards. Journal of Business Ethics, vol. 125, n. 2, pp. 177-191.

https://doi.org/10.1007/s10551-013-1912-y

Delmas Magali A., Burbano Vanessa Cuerel (2011), The drivers of greenwashing, California Management Review, vol. 54, n. 1, pp. 64-87.

https://doi.org/10.1525/cmr.2011.54.1.64

Dawkins Jenny, Lewis Stewart (2003), CSR in Stakeholde Expectations: And Their Implication for Company Strategy, Journal of Business Ethics, vol. 44, n. 2-3, pp 185-193.

https://doi.org/10.1023/A:1023399732720

Fassin, Y., \& Buelens, M. (2011). The hypocrisy-sincerity continuum in corporate communication and decision making: A model of corporate social responsibility and business ethics practices. Management Decision, 49(4), 586-600.

https://doi.org/10.1108/00251741111126503

Freeman Edwards, Harrison Jeffrey, Wicks Andrew, Parmar Bidhan, De Colle Simone (2010), Stakeholder Theory, The State of the Art, Cambridge University Press

Gnecchi Flavio (2006), Corporate Governance Communications, Symphonya. Emerging Issues in Management (symphonya.unimib.it), n. 1, pp. 47-61

http://dx.doi.org/10.4468/2006.1.04gnecchi

Hanss Daniel, Gisela Böhm (2012) Sustainability seen from the perspective of consumers, International Journal of Consumer Studies, vol 36, n. 6, pp. 678-687.

http://dx.doi.org/10.1111/j.1470-6431.2011.01045.x

Hur Won-Moo, Kim Hanna, Woo Jeong (2014) How CSR leads to corporate brand equity: Mediating mechanisms of corporate brand credibility and reputation. Journal of Business Ethics, vol. 125, n. 1, pp. 75-86.

https://doi.org/10.1007/s10551-013-1910-0

Jahdi Khosro S., Acikdilli Gaye (2009), Marketing Communications and Corporate Social Responsibility (CSR): Marriage of Convenience or Shotgun Wedding?, Journal of Business Ethics vol. 88,n.1, pp. 103-113.

https://doi.org/10.1007/s10551-009-0113-1

Kitchen Philip, Schultz Don (2003), Integrated Corporate And Product Brand Communication (1). Journal of Competitiveness Studies, vol. 11, n.1, pp. 66-86.

Lambin Jean-Jacques, Brondoni Silvio M. (2000), Ouverture de 'Market-Driven Management', Symphonya. Emerging Issues in Management (www.unimib.it/symphonya), n. 2, 2000-2001, pp. 7-1 8 http://dx.doi.org/10.4468/2001.2.01

Lambin Jean-Jacques (2009), Capitalism and Sustainable Development, Symphonya. Emerging Issues in Management (symphonya.unimib.it), n. 2, pp. 3-9

http://dx.doi.org/10.4468/2009.2.02lambin

Matute-Vallejo Jorge, Bravo Rafael, Pina Jose (2011), The influence of corporate social responsibility and price fairness on customer behaviour: evidence from the financial sector. Corporate Social Responsibility and Environmental Management, vol. 18, n.6, pp. 317-331 
http://dx.doi.org/10.1002/csr.247

McWilliams, Abagail, Donald Siegel (2001), "Corporate Social Responsibility: A Theory of the Firm Perspective." The Academy of Management Review 26, no. 1 (2001): 117-27.

http://www.jstor.org/stable/259398

Mosca Fabrizio, Casalegno Cecilia, Civera Chiara (2016), Luxury and corporate social responsibility communication strategies. How much does the web matter? A cross investigation on players and consumers' perception, British Academy Management Conference, Newcastle (UK), 6-8 september, 2016.

Mosca Fabrizio, Tamborrini Paolo, Casalegno Cecilia (2015) Systemic Design: How to Compete by Leveraging the Value System, Symphonya. Emerging Issues in Management, n. 2, pp. $42-56$. http://dx.doi.org/10.4468/2015.2.04mosca.tamborrini.casalegno

Perrini Francesco (2005), Building a European Portrait of Corporate Social Responsibility Reporting, European management journal, vol., 23, n. 6, pp. 611-627.

https://doi.org/10.1016/j.emj.2005.10.008

Perrini Francesco, Vurro Clodia (2010), Corporate Sustainability, Intangible Assets Accumulation and Competitive Advantage Constraints, Symphonya. Emerging Issues in Management (symphonya.unimib.it), n. 2, 2010, pp. 25-38.

http://dx.doi.org/10.4468/2010.2.03perrini.vurro

Perrini Francesco, Vurro Clodia (2013) Stakeholder Orientation and Corporate Reputation: A Quantitative Study on US Companies, Symphonya. Emerging Issues in Management, n. 1, pp. 53 65. http://dx.doi.org/10.4468/2013.1.04perrini.vurro

Pomering Alan, Dolnicar Sara (2009), Assessing the prerequisite of successful CSR implementation: are consumers aware of CSR initiatives? Journal of Business Ethics, n.85, pp. 285-301 https://doi.org/10.1007/s10551-008-9729-9

Porter Michael E., Kramer Mark R. (2002), The competitive advantage of corporate philanthropy. Harvard business review, vol. 80., n. 12, pp. 56-68.

https://doi.org/10.4236/ojbm.2016.41011

Ricotti Paolo (2003), Corporate Responsibility and Sustainable Development, Symphonya. Emerging Issues in Management (symphonya.unimib.it), n. 1, spp. 84-98

http://dx.doi.org/10.4468/2003.1.08ricotti

Salvioni Daniela M., Bosetti Luisa (2014) Sustainable Development and Corporate Communication in Global Markets, Symphonya. Emerging Issues in Management (symphonya.unimib.it), n. 1, pp. 1-19 http://dx.doi.org/10.4468/2014.1.03salvioni.bosetti

Sankar Sen, C.B. Bhattacharya (2001) Does Doing Good Always Lead to Doing Better? Consumer Reactions to Corporate Social Responsibility. Journal of Marketing Research: May 2001, Vol. 38, No. 2, pp. 225-243. https://doi.org/10.1509/jmkr.38.2.225.18838

Siano Alfonso, Vollero Agostino, Siglioccolo Mario (2015), Corporate communication management. Torino: Giappichelli.

Sim Yeong Liang, Putuhena Frederik Josep (2015), Green building technology initiatives to achieve construction quality and environmental sustainability in the construction industry in Malaysia. Management of Environmental Quality: An International Journal, vol. 26, n.2, pp. 233-249.

https://doi.org/10.1108/meq-08-2013-0093

Vallaster Christine, Lindgreen Adam, Maon François (2012), Strategically Leveraging Corporate Social Responsibility: A Corporate Branding Perspective, California Management Review, vol. 54, n. 3, 34-60. https://doi.org/10.1525/cmr.2012.54.3.34

van de Ven Bert (2008), An Ethical Framework for the Marketing of Corporate Social Responsibility, Journal of Business Ethics, vol 82, n.2, 339-352.

https://doi.org/10.1007/s10551-008-9890-1

Van Riel, Cees, Fombrun Charles (2007), Essentials of corporate communication: Implementing practices for effective reputation management. Routledge 
Veloutsou Cleopatra, Moutinho Luiz (2009), Brand relationships through brand reputation and brand tribalism. Journal of Business Research, vol. 62, n. 3, pp. 314-322

https://doi.org/10.1016/j.jbusres.2008.05.010

Werther William, Chandler David (2005). Strategic corporate social responsibility as global brand insurance. Business Horizons, vol. 48, n.4, pp. 317-324.

https://doi.org/10.1016/j.bushor.2004.11.009

Wheeler Alina (2009), Designing brand identity. Jakarta: John Wiley and Sons Inc. 